\section{Non-invasive vagus nerve stimulation is beneficial in chronic paroxysmal hemicrania}

\section{INTRODUCTION}

Paroxysmal hemicrania $(\mathrm{PH})$ is a rare primary headache disorder characterised by recurrent attacks of severe, strictly unilateral pain, focused around the orbital, supraorbital and temporal regions and associated with autonomic features. Attacks usually occur more than five times a day and last 2-30 min. ${ }^{1}$ The disorder has an absolute response to indomethacin such that patients are rendered pain-free by therapeutic doses. Between $65 \%$ and $88 \%$ of patients suffer from the chronic form of $\mathrm{PH}$ where the attacks occur for more than 1 year without remission or with remission periods lasting less than 3 months. ${ }^{2}$ Over $30 \%$ of patients report dose-limiting side-effects with indomethacin and approximately $20 \%$ discontinue the drug due to tolerability problems. ${ }^{3}$ Although several other drugs have been reported to have efficacy in $\mathrm{PH}$, none offer the same magnitude of response.

Evidence to support the role of the vagus nerve in trigeminal pain have been identified in prior studies. Inhibition of nociceptive activation of the trigeminocervical neurons have been shown in preclinical animal models, with a dose-dependent effect. ${ }^{4}$ Non-invasive vagus nerve stimulation (nVNS), using the gammaCore device, has been reported to be beneficial in trigeminal autonomic cephalalgias (TACs). A recent audit looking at 15 patients with indomethacin-responsive headaches, six of whom had $\mathrm{PH}$, concluded that nVNS may be an important adjunct or alternative in those patients with TACs. ${ }^{5}$

\section{METHOD}

Given these results, we tried nVNS in eight chronic paroxysmal hemicrania $(\mathrm{CPH})$ patients who were intolerant of indomethacin. Patients were diagnosed as CPH based on ICHD-3 beta criteria. ${ }^{1}$ At initial presentation, some patients reported attacks lasting more than 30 min though most of the attacks lasted less than $30 \mathrm{~min}$; occasional prolonged attacks are a common feature in $\mathrm{PH}^{2}$ Prior to use, all patients had complete suppression of headaches with indomethacin but experienced significant side effects. One patient was on a stable dose of pregabalin prior to starting nVNS, the remainder were not on concomitant medication use. Treatment with nVNS was offered as a 'humanitarian intervention' and ethics board approval for the collection and publication of data was granted by Northwick Park Hospital Research Ethics Committee, Hampstead, London, UK (REC Number. 11/ LO/1709).

Patients administered two consecutive doses three times a day ipsilateral to the pain. The stimulator has a predetermined duration of $2 \mathrm{~min}$ and patients can change the stimulation intensity. The patients in this group were asked to increase the stimulation until the point of 'lip pull' to ensure optimal stimulation. They were trained on how to use the device and their technique was checked 4 weeks 
Table 1 Non-invasive vagal nerve stimulation in chronic paroxysmal hemicrania

\begin{tabular}{|c|c|c|c|c|c|c|c|c|}
\hline Patient number & 1 & 2 & 3 & 4 & 5 & 6 & 7 & 8 \\
\hline Age & 52 & 52 & 28 & 20 & 43 & 44 & 81 & 63 \\
\hline Sex & Male & Male & Male & Female & Female & Male & Male & Female \\
\hline $\begin{array}{l}\text { Duration of CPH } \\
\text { (years) }\end{array}$ & 3 & 11 & 3 & 6 & 22 & 11 & 8 & 5 \\
\hline \multicolumn{9}{|c|}{ Headache characteristics at diagnosis } \\
\hline Frequency & $8-12 /$ day & $6-8 /$ day & 5-9/day & 4-13/day & 10-20/day & 5-20/day & 4-12/day & 5-12/day \\
\hline Severity (VRS) & 10 & $5-10$ & $7-10$ & $8-10$ & $6-10$ & $4-8$ & 10 & $8-10$ \\
\hline Duration (min) & $15-30$ & $15-45$ & $15-60$ & $15-120$ & $5-90$ & $5-120$ & $5-20$ & $5-45$ \\
\hline $\begin{array}{l}\text { Median duration } \\
\text { (min) }\end{array}$ & 20 & 20 & 25 & 20 & 10 & 30 & 15 & 15 \\
\hline Indometacin dose & $225 \mathrm{mg}$ & $100 \mathrm{mg}$ & $225 \mathrm{mg}$ & $75 \mathrm{mg}$ & $225 \mathrm{mg}$ & $225 \mathrm{mg}$ & $100 \mathrm{mg}$ & $225 \mathrm{mg}$ \\
\hline $\begin{array}{l}\text { Side effects from } \\
\text { indometacin }\end{array}$ & Severe lethargy & colitis & $\begin{array}{l}\text { Severe } \\
\text { gastrointestinal } \\
\text { upset }\end{array}$ & $\begin{array}{l}\text { Severe } \\
\text { gastrointestinal } \\
\text { upset }\end{array}$ & $\begin{array}{l}\text { Swollen ankles } \\
\text { and marked } \\
\text { lethargy }\end{array}$ & $\begin{array}{l}\text { Severe } \\
\text { gastrointestinal } \\
\text { upset }\end{array}$ & Duodenal ulcer & $\begin{array}{l}\text { Severe } \\
\text { gastrointestinal } \\
\text { upset }\end{array}$ \\
\hline $\begin{array}{l}\text { Preventive } \\
\text { treatments failed }\end{array}$ & 3 & 4 & 3 & 3 & 4 & 5 & 3 & 1 \\
\hline $\begin{array}{l}\text { Duration of use of } \\
\text { VNS (months) }\end{array}$ & 19 & 10 & 6 & 6 & 7 & 5 & 7 & 3 \\
\hline \multicolumn{9}{|c|}{ Baseline headaches (1 month pre-VNS) } \\
\hline Frequency & 5-10/day & 2-3/day & $5 /$ day & $1-2 /$ day & $5 /$ day & 2/day & $4-5 /$ day & $2-5 /$ day \\
\hline Severity (VRS) & 10 & $2-6$ & $7-8$ & $8-10$ & $4-8$ & $5-9$ & 10 & $9-10$ \\
\hline Duration (min) & $20-30$ & $30-90$ & $45-60$ & $15-120$ & $5-80$ & $60-120$ & $15-20$ & $30-45$ \\
\hline \multicolumn{9}{|c|}{ Follow-up at 3 months } \\
\hline Frequency & 2-3 week & $1 /$ day & 2/week & 5/month & $1 /$ day & $1-2 /$ day & 0 & 2-5/day \\
\hline Severity (VRS) & $5-6$ & $2-3$ & $4-5$ & $5-9$ & $1-2$ & $1-2$ & 0 & $9-10$ \\
\hline Duration (min) & $15-20$ & $30-60$ & $20-30$ & $5-20$ & $5-30$ & $30-60$ & 0 & $30-45$ \\
\hline \multicolumn{9}{|c|}{ Follow-up at 6 months } \\
\hline Frequency & $1 /$ week & $1 /$ day & 2/week & 5/month & 0 & $\mathrm{~N} / \mathrm{A}$ & 0 & $\mathrm{~N} / \mathrm{A}$ \\
\hline Severity (VRS) & $6-7$ & $2-4$ & $4-5$ & $5-9$ & 0 & $\mathrm{~N} / \mathrm{A}$ & 0 & $\mathrm{~N} / \mathrm{A}$ \\
\hline Duration (min) & $15-20$ & $30-60$ & $20-30$ & $5-20$ & 0 & $\mathrm{~N} / \mathrm{A}$ & 0 & $\mathrm{~N} / \mathrm{A}$ \\
\hline \multicolumn{9}{|l|}{ Last follow-up } \\
\hline Frequency & $1 /$ week & $1 /$ day & 2/week & 5/month & 0 & $1-2 /$ day & 0 & 2-5/day \\
\hline Severity (VRS) & $6-7$ & $2-4$ & $4-5$ & $5-9$ & 0 & $1-2$ & 0 & $9-10$ \\
\hline Duration (min) & 20 & $30-60$ & $20-30$ & $5-20$ & 0 & $30-60$ & 0 & $30-45$ \\
\hline \multicolumn{9}{|l|}{ HIT-6 } \\
\hline Baseline & 70 & 59 & 69 & 74 & 50 & 48 & 40 & 74 \\
\hline 3 months & 60 & 55 & 59 & 31 & 46 & 48 & 36 & 76 \\
\hline 6 months & 65 & 54 & 59 & 30 & 36 & $\mathrm{~N} / \mathrm{A}$ & 36 & $\mathrm{~N} / \mathrm{A}$ \\
\hline Last follow-up & 66 & 54 & 59 & 30 & 36 & 48 & 36 & $N / A$ \\
\hline \multicolumn{9}{|l|}{ MIDAS } \\
\hline Baseline & 21 & 5 & 190 & 71 & 81 & 0 & 0 & 105 \\
\hline 3 months & 4 & 5 & 167 & 68 & 0 & 0 & 0 & 120 \\
\hline 6 months & 18 & 5 & 78 & 67 & 0 & $\mathrm{~N} / \mathrm{A}$ & 0 & $N / A$ \\
\hline Last follow-up & 14 & 5 & 78 & 67 & 0 & 0 & 0 & $\mathrm{~N} / \mathrm{A}$ \\
\hline \multicolumn{9}{|l|}{ HADS-A } \\
\hline Baseline & 2 & 9 & 12 & 17 & 20 & 2 & 1 & 18 \\
\hline 3 months & 6 & 6 & 4 & 18 & 19 & 0 & 0 & 17 \\
\hline 6 months & 5 & 6 & 0 & 19 & 19 & $\mathrm{~N} / \mathrm{A}$ & 0 & $\mathrm{~N} / \mathrm{A}$ \\
\hline Last follow-up & 3 & 6 & 0 & 19 & 19 & 0 & 0 & $\mathrm{~N} / \mathrm{A}$ \\
\hline \multicolumn{9}{|l|}{ HADS-D } \\
\hline Baseline & 3 & 6 & 14 & 14 & 16 & 2 & 1 & 15 \\
\hline 3 months & 1 & 5 & 7 & 14 & 9 & 0 & 0 & 16 \\
\hline 6 months & 3 & 5 & 0 & 15 & 9 & N/A & 0 & $\mathrm{~N} / \mathrm{A}$ \\
\hline Last follow-up & 6 & 5 & 15 & 15 & 9 & 0 & 0 & $\mathrm{~N} / \mathrm{A}$ \\
\hline $\begin{array}{l}\text { Patients estimate } \\
\text { of improvement }\end{array}$ & $70 \%$ & $70 \%$ & $90 \%$ & $80 \%$ & $100 \%$ & $65 \%$ & $100 \%$ & $0 \%$ \\
\hline
\end{tabular}

CPH, chronic paroxysmal hemicrania; HADS-A/D, Hospital Anxiety and Depression Scale-Anxiety/Depression; HIT-6, Headache Impact Test-6; MIDAS, Migraine Disability Assessment; N/A, no data available; VNS, vagus nerve stimulation; VRS, verbal rating scale (0-10; 0 pain free, 10 very severe pain). 
later to ensure it was optimal. Prospective headache diaries were kept at baseline and throughout follow-up. Patients were followed up every 3-6 months when data were collected on headache disability scores (Migraine Disability Assessment Score (MIDAS) and Headache Impact Test (HIT-6) and affective measures (Hospital Anxiety and Depression Scale (HADS)).

ElectroCore supplied the devices through a cost sharing programme; the device was supplied free of charge for 3 months and thereafter the device was paid for either by the patient or the healthcare provider.

\section{RESULTS}

The results of this case series are shown in table 1 . The group consisted of eight patients (five males) with a mean age of 48 years (range: $20-81$ years) and median duration of CPH of 8 years (range 3-22 years). Patients had failed to respond to an average of three preventive medications (range: 1-5) and all had dose limiting side effects to indomethacin. Median follow-up of the cohort was 7 months (3-19 months). At 3 months, the mean monthly headache frequency fell by 68.01\% $(p=0.012)$ but further dropped to $75 \%(p=0.003)$ at the final follow-up. A favourable response, defined as a more than 50\% reduction in monthly headache frequency, was observed in $75 \%$ of patients at final follow-up. The median time to reach a $50 \%$ improvement was 3 months (range: 3-6 months). There was a reduction in median severity of attacks from verbal rating score (VRS) 8/10 to $6 / 10(p=0.050)$ at 3 months follow-up. At final follow-up, the median severity of attacks dropped from VRS $8 / 10$ to $4 / 10$ $(p=0.011)$. Similarly, there was a reduction in the median duration of attacks from $47.5 \mathrm{~min}$ to $21.25 \mathrm{~min}$ at 3 months follow-up $(p=0.007)$ and at final follow-up to $23.1 \mathrm{~min}(\mathrm{p}=0.007)$. Significant reductions were reported in HIT-6 and MIDAS scores. Seven patients showed a reduction in the Hospital Anxiety (HAD-A) scores, while four patients showed a reduction in the Hospital Depression (HAD-D) scores.
The average estimated global improvement was $64.37 \%$ and $71.88 \%$ at 3 months and final follow-up, respectively. No adverse events were reported by any patients.

\section{DISCUSSION}

Our experience suggests that nVNS has potential use as a preventative therapy for $\mathrm{PH}$ in patients unable to tolerate indomethacin. As detailed above, six of the eight patients had more than 50\% reduction in frequency in their monthly headaches with significant improvements in their disability scores. We identified a 75\% favourable response with two patients becoming attack-free.

There are limitations to these data, including those inherent to any unblinded series, though despite this our results are encouraging. The strength of the current series includes the use of prospective data. Further research into the use and safety of $\mathrm{nVNS}$ in $\mathrm{PH}$ is required. However, given the rarity of $\mathrm{PH}$, it is unlikely that an adequately powered, randomised controlled trial will occur in the near future. Our results nonetheless highlight the potential importance of $\mathrm{nVNS}$ in this patient group and also the need to ensure patients adhere to treatment for at least 3 months given the latency to median treatment efficacy.

\section{CLASSIFICATION OF EVIDENCE Class IV.}

\section{Salwa Kamourieh, ${ }^{1}$ Susie Lagrata, ${ }^{1}$ Manjit Singh Matharu ${ }^{1,2}$}

${ }^{1}$ Headache Group, The National Hospital for Neurology and Neurosurgery, London, UK

${ }^{2}$ UCL Institute of Neurology, London, UK

Correspondence to Dr Manjit Singh Matharu, Headache Group, Institute of Neurology and The National Hospital for Neurology and Neurosurgery, Queen Square, London WC1N 3BG, UK; m.matharu@ uclmail.net

Contributors SK: analysis and interpretation of data, drafting and revision of manuscript. SL: data collection, analysis and interpretation of data and revision of manuscript. MSM: study concept, recruitment of subjects, interpretation of data and manuscript revision.
Competing interests SK and SL reports no disclosures. MSM serves on the advisory board for Allergan, St Jude Medical and Medtronic and has received payment for the development of educational presentations from electroCore, Allergan, Medtronic and St Jude Medical.

Patient consent for publication Obtained.

Ethics approval Northwick Park Hospital Research Ethics Committee, Hampstead, London, UK.

Provenance and peer review Not commissioned; externally peer reviewed.

Data sharing statement Raw data may be made available on written request to the corresponding author.

\section{(6) OPEN ACCESS}

Open access This is an open access article distributed in accordance with the Creative Commons Attribution Non Commercial (CC BY-NC 4.0) license, which permits others to distribute, remix, adapt, build upon this work non-commercially, and license their derivative works on different terms, provided the original work is properly cited, appropriate credit is given, any changes made indicated, and the use is non-commercial. See: http:// creativecommons.org/licenses/by-nc/4.0/.

(C) Author(s) (or their employer(s)) 2019. Re-use permitted under CC BY-NC. No commercial re-use. See rights and permissions. Published by BMJ.

\section{Check for updates}

To cite Kamourieh S, Lagrata S, Matharu MS. J Neurol Neurosurg Psychiatry 2019;90:1072-1074.

Received 15 September 2018

Revised 16 November 2018

Accepted 5 December 2018

Published Online First 1 February 2019

J Neurol Neurosurg Psychiatry 2019;90:1072-1074. doi:10.1136/jnnp-2018-319538

\section{REFERENCES}

1 Headache Classification Subcommittee of The International Headache Society. The international classification of headache disorders. 3rd edn, 2013: 629-808.

2 Cittadini E, Matharu MS, Goadsby PJ. Paroxysmal hemicrania: a prospective clinical study of 31 cases. Brain 2008;131:1142-55.

3 Dodick DW. Indomethacin-responsive headache syndromes. Curr Pain Headache Rep 2004;8:19-26.

4 Akerman S, Simon B, Romero-Reyes M. Vagus nerve stimulation suppresses acute noxious activation of trigeminocervical neurons in animal models of primary headache. Neurobiol Dis 2017;102:96-104.

5 Tso AR, Marin J, Goadsby PJ. Noninvasive vagus nerve stimulation for treatment of indomethacin-sensitive headaches. JAMA Neurol 2017;74:1266-7. 